\title{
MEMBANGUN BUDAYA MUTU PADA LEMBAGA PENDIDIKAN ISLAM MENUJU MADRASAH UNGGUL
}

\author{
Amir \\ Institut Agama Islam Negeri, Jember, Indonesia \\ Email : amiriainjember@gmail.com
}

DOI: https://doi.org/10.33650/al-tanzim.v3i2.676

\begin{tabular}{l|l|c} 
Received: September 2019 & Revised: November 2019 & Approved: November 2019 \\
\hline
\end{tabular}

\begin{abstract}
:
This paper presents the efforts of madrasah in building a quality culture towards superior madrasah in Madrasah Aliyah Nurul Hikam, Kapongan, Situbondo. This is done in order to meet the complexity of the demands of society and respond to the changing times, especially in entering the era of the industrial revolution 4.0. The efforts made by Madrasah Aliyah Nurul Hikam in building a quality culture towards superior madrasah namely; 1) designing high performance-oriented attitudes and behavioral standards, both for the headmaster, administrative staff, teachers and students, 2) formulating the best service standards that must be obeyed by all madrasah residents to improve the quality of service to customers, especially students and parents, 3) integrating quality culture in all activities in madrasah, 4) giving awards to madrasah who have high achievements and providing guidance for those who have low performance, 5) providing motivation to madrasah to continue to improve their performance to suit the expectations of all parties, so that a superior madrasah quality can be created.
\end{abstract}

Key words : Quality Culture, madrasah, Superior Educational Institutions

\begin{abstract}
Abstrak
Tulisan ini menyajikan tentang upaya madrasah dalam membangun budaya mutu menuju madrasah unggul di Madrasah Aliyah Nurul Hikam, Kapongan, Situbondo. Hal ini dilakukan dalam rangka memenuhi kompleksitas tuntutan masyarakat dan merespon perkembangan zaman yang terus berubah, khususnya dalam memasuki era revolusi industri 4.0. Adapun upaya yang dilakukan oleh Madrasah Aliyah Nurul Hikam dalam membangun budaya mutu menuju madrasah unggul yaitu; 1) mendesain standar sikap dan perilaku yang berorientasi pada kinerja yang tinggi, baik bagi kepala madrasah, staff administrasi, para guru maupun siswa, 2) merumuskan standar pelayanan terbaik yang harus dipatuhi oleh semua warga madrasah untuk meningkatkan mutu layanan kepada pelanggan, khususnya siswa dan orang tua siswa, 3) pengintegrasian budaya mutu dalam seluruh aktivitas di madrasah, 4) memberikan penghargaan bagi warga madrasah yang memiliki prestasi tinggi dan memberikan pembinaan bagi mereka yang memiliki kinerja rendah, 5) memberikan motivasi kepada warga madrasah untuk terus meningkatkan kinerjanya agar sesuai dengan harapan semua pihak, sehingga dapat tercipta mutu madrasah yang unggul.

Kata Kunci : Budaya Mutu, madrasah, Lembaga Pendidikan Unggul
\end{abstract}




\section{PENDAHULUAN}

Setiap lembaga pendidikan memiliki tanggung jawab yang besar agar proses dan hasil pendidikan bisa dicapai sesuai dengan tujuan yang telah ditetapkan, tidak terkecuali, Madrasah Aliyah Nurul Hikam, Kesambirampak, Kapongan, Situbondo. Salah satu implikasi globalisasi dalam pendidikan, yaitu adanya regulasi yang memungkinkan peluang lembaga pendidikan asing membuka sekolahnya di Indonesia. Oleh karena itu, persaingan antar lembaga penyelenggara pendidikan dan pasar kerja akan semakin berat (Ahmed Hamadtu Ahmed \& Gumaa Siddiek, 2012). Peningkatan mutu pendidikan menjadi hal yang perlu ditingkatkan untuk mengantisipasi perubahanperubahan yang begitu cepat serta tantangan yang semakin besar dan kompleks. Peningkatan mutu merupakan salah satu jalan yang dilalui untuk memelihara serta mempertahankan eksistensi organisasi (Mandru, Patrascu, Carstea, Popescu, \& Birsan, 2011).

Berangkat dari hal tersebut, Madrasah Aliyah Nurul Hikam, Kesambirampak, Kapongan, Situbondo mengupayakan segala cara untuk meningkatkan mutu lembaganya, agar memiliki daya saing yang kuat dan unggul di tengah persaingan institusi pendidikan (Miftachurrohman \& Atika, 2018).

Banyak penelitian yang tentang membangun budaya mutu madrasah, diantaranya; Mohammady (2018) meneliti tentang pengembangan budaya mutu melalui kepemimpinan kepala SDMT Ponorogo, yang dilakukan melalui; melakukan analisis internal dan eksternal, mengikut sertakan pendidik dan tenaga kependidikan dalam pengembangan kualitas sumber daya manusia, mengevaluasi kinerja anggotanya, dan menciptakan budaya organisasi yang harmonis dan berprestasi. Begitu juga dengan Aminah (2019), yang meneliti tentang nilai budaya mutu di MAN 1 Jember dan MA Unggulan Nurul Islam. Hasil penelitiannya menunjukkan bahwa nilai budaya mutu di MAN 1 Jember menekankan pada aspek ubudiyyah dan kegiatan ekstrakurikuler akademik. Budaya unggul di MA Unggulan Nuris yaitu budaya membaca, berperilaku disiplin, inovatif dan kreatif.

Mutu madrasah merupakan sesuatu yang absolut dan harus dipertahankan serta dilestarikan (Kurniawan, 2017), dijadikan sebuah budaya, sehingga kualitas madrasah terjamin. Menurut Garvin sebagaimana dikutip Said (2018), ada lima macam perspektif mutu yaitu : (1) transcendental approach, dimana kualitas dapat dirasakan, diketahui, tapi sulit didefinisikan, (2) product based approach, suatu kualitas merupakan atribut atau spesifikasi secara kuantitatif yang dapat diukur, (3) use based approach, sebuah kualitas tergantung pada orang yang memandangnya sehingga pelayanan yang paling memuaskan preferensi seseorang merupakan pelayanan yang paling tinggi sehingga pelanggan yang berbeda memiliki kebutuhan dan keinginan yang berbeda pula sehinnga kualitas bagi seseorang adalah sama dengan kepuasan maksimum yang dirasakan, (4) manufacturing based approach, ialah menentukan kualitas 
Al-Tanzim : Jurnal Manajemen Pendidikan Islam E-ISSN: 2549-5720 P-ISSN: 2549-3663

Vol. 03 No. 02 (2019) : 1-12

https:// ejoumal.unija.ac.id/ index.php/al-tanzim

yang sudah distandarkan, (5) value based approach, ialah memandang kualitas dari segi nilai dan kemanfaatannya yang paling bermakna dari pelanggan.

Berdasarkan pendapat tersebut di atas, penelitian ini memiliki keunikan dan kebaruan dalam pengelolaan madrasah yang berbasis kearifan local dalam membangun budaya mutu menuju madrasah unggul di Madrasah Aliyah Nurul Hikam, Kapongan, Situbondo.

\section{Budaya Mutu dalam Lembaga Pendidikan}

Menurut Syaiful Sagala, budaya adalah suatu konsep yang membangkitkan minat dan berkenaan dengan cara manusia hidup, belajar berfikir, merasa, mempercayai dan mengusahakan apa yang patut menurut budayanya (Sagala, 2008). Sedangkan mutu menurut Edward Sallis sebagaimana dikutip oleh Choiri (2015) adalah konsep tentang kualitas sesuatu yang bersifat absolut sekaligus juga bersifat relative. Sesuatu yang bermutu bersifat absolut merupakan bagian dari standar yang sangat tinggi dan tidak dapat diungguli. Sesuatu yang bermutu bersifat relatif dipandang sebagai suatu produk yang sesuai dengan kebutuhan pelanggannya (Aole \& Gorantiwar, 2013).

Budaya sekolah atau dikenal dengan school culture merupakan faktor penting dalam membentuk peserta didik menjadi manusia yang penuh optimis, berani tampil, berperilaku kooperatif, mempunyai kecakapan personal dan akademik. Dengan kata lain, budaya mutu dapat digunakan untuk menjelaskan upaya membangkitkan minat dan berkenaan dengan cara sekolah menghasilkan suatu produk memenuhi kriteria atau rujukan tertentu.

Budaya mutu merupakan sebuah sistem nilai organisasi yang menghasilkan lingkungan yang kondusif demi keberlangsungan dan keberlanjutan perbaikan mutu. Budaya mutu terdiri dari nilai-nilai, tradisi, prosedur, dan harapan tentang promosi mutu. Budaya mutu madrasah adalah sistem nilai organisasi/madrasah yang menciptakan lingkungan yang kondusif untuk keberlangsungan perbaikan mutu yang berkesinambungan. Budaya mutu madrasah terdiri dari nilai-nilai, tradisi, prosedur dan harapan tentang promosi mutu. Sedangkan tujuan dari budaya mutu madrasah adalah untuk membentuk suatu lingkungan organisasi yang memiliki sistem nilai, tradisi, dan aturan-aturan yang mendukung untuk mencapai perbaikan mutu secara terus menerus. Budaya mutu merupakan suatu pola, nilai-nilai, keyakinan dan harapan anggota organisasi kepada pekerjaannya untuk menghasilkan produk dan perkhidmatan yang berkualitas (Amin, Siswanto, \& Hakim, 2018).

Terdapat beberapa faktor yang mempengaruhi terhadap budaya mutu di madrasah; yaitu: 1) nilai-nilai dan misi madrasah, 2) struktur organisasi, 3) komunikasi, 4) pengambilan keputusan, 5) lingkungan kerja, 6) rekrutmen dan seleksi, 7) perencanaan kurikulum, 8) manajemen sumber daya dan anggaran, 9) disiplin, 10) hubungan masyarakat. Mutu sebuah madrasah juga dapat dilihat dari tertib administrasinya. Adapun salah satu bentuk tertib 
administrasi adalah adanya mekanisme kerja yang efektif dan efesien, baik secara vertikal ataupun horizontal (Midun, 2017).

Budaya mutu dimulai dengan komitmen mutu dari semua komponen sekolah, kerjasama, dan kepemimpinan yang kuat dalam madrasah. Budaya mutu madrasah melalui proses manajemen madrasah yang dapat dilakukan mulai tahap perencanaan, pengorganisasian, kepemimpinan, dan pengawasan (Riyanta, 2016).

Budaya mutu dalam pendidikan dilaksanakan dengan meningkatkan pelayanan untuk memenuhi keinginan dan harapan dari para pelanggan. Edward Sallis (Mulyadi, 2010) menyebutkan, bahwasannya pelanggan dalam pendidikan dibagi menjadi tiga kelompok, yaitu: (1) pelajar yang secara langsung menerima jasa, (2) orang tua atau sponsor pelajar yang memiliki kepentingan langsung secara individu maupun institusi, (3) pihak yang memiliki peran penting, meskipun tak langsung seperti pemerintah dan masyarakat secara keseluruhan. Keragaman pelanggan tersebut membuat seluruh institusi pendidikan harus lebih memfokuskan perhatian mereka pada keinginan para pelanggan dan mengembangkan mekanisme untuk merespon mereka.

Kriteria manajemen madrasah berbudaya mutu ditandai 5 (lima) pilar mutu pendidikan, yaitu: (1) Fokus pada siswa (peserta didik). Bahwa madrasah dan para professional pendidikan memiliki tanggung jawab yang besar untuk selalu mengoptimalkan potensi-potensi siswa agar mendapat manfaat dari proses belajar di madrasah. Dengan kata lain, dalam proses kegiatan belajar mengajar harus dipersiapkan dengan baik, dikelola secara professional agar dapat memberikan nilai manfaat yang besar bagi pengembangan potensi siswa. (2) Keterlibatan total. Setiap orang harus berpartisipasi dalam transformasi mutu. Mutu bukan hanya tanggung jawab kepala madrasah, mutu merupakan tanggung jawab semua pihak yaitu, komite, guru, staf, orang tua, bahkan siswa itu sendiri. Mutu, berarti menuntut kepada setiap orang untuk memberikan kontribusi bagi upaya mutu. (3) Pengukuran. Pengukuran merupakan bidang yang sering kali banyak gagal di madrasah, karena setiap yang dikerjakan tidak diiringi pengukuran untuk mengetahui tingkat keberhasilannya. Secara tradisional ukuran mutu pada keluaran madrasah adalah prestasi siswa. (4) Komitmen. Para professional pendidikan harus memiliki komitmen pada mutu. Jika mereka tidak memiliki komitmen, maka proses transformasi mutu tidak akan dapat dimulai, karena terpaksa dijalankan maka dipastikan akan gagal. Hal ini berarti perlu adanya perubahan budaya dan manajemen yang memiliki komitmen untuk mendukung proses perubahan kearah peningkatan mutu. (5) Perbaikan berkelanjutan (continous improvment). Mutu didasarkan pada sebuah konsep, bahwa setiap proses itu dapat diperbaiki dan tidak ada proses yang sempurna. Maka para profesional pendidikan harus konstan menemukan cara untuk menangani masalah yang muncul, mereka harus memperbaiki proses yang dikembangkannya dan membuat perbaikan yang diperlukan (Jabar, 2011). 
Al-Tanzim : Jurnal Manajemen Pendidikan Islam E-ISSN: 2549-5720 P-ISSN: 2549-3663

Vol. 03 No. 02 (2019) : 1-12

bttps:/ / ejournal.unija.ac.id/ index.php/al-tanzim

\section{Lembaga Pendidikan Unggul; Sebuah Asa}

Keunggulan dimaknai sebagai suatu kondisi yang mampu melampaui harapan, keinginan atau standar yang ditetapkan. Keunggulan madrasah meliputi aspek input, out put, dan out come pendidikan (Saufi \& Hambali, 2019). Madrasah unggul adalah madrasah yang mampu membawa setiap siswa mencapai kemampuannya secara terukur dan mampu menunjukkan prestasinya. Madrasah unggul dianggap madrasah yang bermutu, namun dalam penerapannya, banyak kalangan menganggap bahwa dalam katagori unggulan tersirat harapan apa yang dapat diberikan kepada siswa pada saat lulus. Harapan itu sangat penting dan sangat dibutuhkan oleh setiap orang tua siswa, pemerintah, masyarakat bahkan oleh siswa itu sendiri, yaitu sejauh mana (out put) dan (out come) madrasah memiliki kemampuan intelekual, moral dan keterampilan yang dapat berguna bagi masyarakat, negara dan agama (Rahmah, 2016).

Sekolah unggul pada prinsipnya harus memiliki ciri-ciri khusus dan dapat menjadi dasar utama dalam menentukan unggul tidaknya sebuah lembaga pendidikan. Ciri-ciri madrasah unggul adalah: (1) memiliki siswa dengan bakat-bakat khusus dan kemampuan serta kecerdasan yang tinggi, (2) memiliki tenaga pengajar yang profesional dan handal, (3) memiliki kurikulum yang diperkaya (eskalasi), (4) memiliki sarana dan prasarana yang baik, seperti ruang kelas, taman bermain, laboratorium dan ruang komputer yang lengkap peralatannya, perpustakaan, lapangan olah raga yang dapat meningkatkan prestasi siswa, media belajar yang cukup lengkap, buku pelajaran dengan perbandingan 1 siswa : 1 buku untuk setiap mata pelajaran, mushalla yang bersih dan rapi, tenaga konseling dan ruang konseling. Ruang konseling harus dilengkapi dengan kotak P3K, tempat tidur, dan peralatan lainnya. Jumlah siswa dalam kelas maksimum 30 orang (Chiar, 2009).

Ciri-ciri madrasah unggul sebagai berikut; (a) nilai prestasi dan persaingan, (b) nilai keefektifan, (c) kedisiplinan, (d) kemandirian, (e) prestise (kebanggaan). Prestasi dan persaingan merupakan dua nilai terpisah, namun keduanya dapat dipasangkan. Prestasi diukur dengan standar pencapaian, sedangkan persaingan diukur dengan membandingkan prestasi seorang anak dengan anak lain, atau satu sekolah dengan sekolah lain. Keefektifan terwujud dalam pelaksanaan kerja, baik siswa, guru maupun madrasah secara institusional. Keefektifan madrasah juga ditandai oleh kepemimpinan pengajaran yang kuat, fokus hasil belajar yang jelas, ekspektasi yang tinggi terhadap siswa, lingkungan yang nyaman dan teratur. Kedisiplinan, esensi nilai kedisiplinan terkait dengan ketepatan waktu dan kepatuhan terhadap tata tertib atau peraturan. Kemandirian, merupakan kemampuan serta keberanian mengambil keputusan dan siap menanggung resiko atas keputusannya.

Dalam kehidupan individu atau kelompok, kemandirian tidak berarti isolasi, eksklusifisme, akan tetapi sebaliknya, ia bercirikan keterbukaan, interdependensi, kepedulian, kerjasama dan harga diri. Prestise, nilai ini yang 
melekat dengan status, yaitu status madrasah yang memiliki reputasi, gengsi, dan nama baik. Siswa, orang tua, maupun guru menjadi bagian dari madrasah tersebut, maka dalam diri mereka juga merasa bangga terhadap reputasi sekolah (Rahmah, 2016).

Madrasah unggul harus mampu mengelola siswa untuk dijadikan peribadi yang tumbuh dan berkembang sesuai dengan karakteristik individualnya. Madrasah unggul juga mampu dan sanggup mendidik sisiwanya untuk menguasai sains dan teknologi. Kriteria tersebut mencakup: (1) guru profesional yang memiliki kompetensi yang tinggi dalam menguasai kurikulum, materi pembelajaran, metode, strategi, dan pendekatan pembelajaran dengan kualitas yang tinggi, (2) berprestasi, menguasai teknikteknik evaluasi pembelajaran, dan menguasai strategi pembelajaran yang unggul, (3) memiliki disiplin dan berdedikasi tinggi, setia terhadap tugas, inovatif, kreatif dalam mendidik, mengasuh, dan membimbing siswa yang memiliki bakat dan potensi yang unggul, (4) sehat jasmani dan ruhani, energik, berpenampilan, berbudi pekerti luhur, dan senior dalam jenjang pangkat atau pengalamannya, (5) memiliki kelebihan khusus dibanding guru lainnya baik dalam bidang keterampilan, mengampu suatu mata pelajaran khusus, dan membimbing siswa mata materi ekstrakurikuler (Rahmah, 2016).

Hasbullah (Pawito, 2007) menyebutkan, sekolah/madrasah dianggap memiliki daya tarik, daya saing dan daya tahan, setidaknya sekolah harus memiliki syarat-syarat sebagai berikut; Pertama, Sekolah sebagai tempat proses pembelajaran berkualitas dan hasilnya bermutu. Berkualitas dalam bidang akademik, pendampingan emosional, dan pembimbingan spiritual, kedua, biaya sekolah sebanding dengan kualitas yang diperlihatkannya. Orang tua yang menyadari akan pentingnya kualitas pendidikan, walaupun biaya sedikit mahal asal kualitas yang diberikan bagus maka bukan menjadi persoalan. Pendidikan bukanlah sebuah usaha bisnis, di mana dalam dunia bisnis dikenal istilah yang bermutu itu mahal dan yang tidak bermutu itu murah. Pendidikan memiliki barometer lain dalam melihat sisi pembiayaan. Ada beberapa sekolah di Indonesia yang terkesan murahan, namun mampu mendidik siswa dengan baik. Hal tersebut tidak terlepas dari peran siswa yang ada di dalamnya.

Ketiga, sekolah memiliki etos kerja yang tinggi, dalam arti semua komponen pendidikan telah terbiasa untuk bekerja keras mendidik, tertib, disiplin, penuh tanggung jawab, objektif, dan konsisten. Nilai-nilai tersebut menjadi sikap dan milik seluruh anggota dan komunitas pendidikan pada sekolah ini, keempat, terjamin sisi keamanan baik pisik dan psikologis. Dalam arti, komplek sekolah sungguh-sungguh menanamkan sikap ramah lingkungan untuk hidup tertib, indah, rapi, aman, rindang, nyaman dan menjadikan orang betah di dalamnya, kelima, tercipta suasana humanis di dalam sekolah, terpeliharanya budaya komunikasi, latihan bersama dan adanya validasi teman sejawat. Dengan kata lain, sekolah yang baik terpeliharanya integritas pendidikan, religiusitas, moral, karakter dan akhlaknya. 
Al-Tanzim : Jurnal Manajemen Pendidikan Islam

E-ISSN: 2549-5720 P-ISSN: 2549-3663

Vol. 03 No. 02 (2019) : 1-12

https:// ejournal.unuja.ac.id/index.php/ al-tanzim

\section{METODE PENELITIAN}

Penelitian ini menggunakan pendekatan kualitatif jenis studi kasus. Penelitian ini ingin mengungkap tentang fenomena yang terjadi di madrasah, terkait dengan upaya madrasah dalam membangun budaya mutu menuju madrasah unggul di Madrasah Aliyah Nurul Hikam, Kapongan, Situbondo. Dalam hal ini peneliti melakukan penelitian secara intensif, terinci serta mendalam tentang suatu tatanan organisasi, lembaga ataupun gejala-gejala tertentu (Zahroh, 2014). Tekhnik pengumpulan data dilakukan melalui wawancara mendalam terhadap informan yang ada, ditunjang dengan observasi terhadap beberapa aktivitas yang ada pada subyek penelitian, dan dilanjutkan dengan mendokumentasikan beberapa dokumen yang relevan sesuai dengan temuan di lapangan. Sedangkan analisis datanya dilakukan secara sirkuler, yang dimulai dari, penyajian data, reduksi data dan penarikan kesimpulan penelitian.

\section{HASIL PENELITIAN DAN PEMBAHASAN}

\section{Membangun Budaya Mutu pada Lembaga Pendidikan Islam Menuju Madrasah Unggul}

Penyelenggaraan lembaga pendidikan yang berorientasi pada mutu merupakan ikhtiar untuk meningkatkan mutu pendidikan agar unggul dan memiliki daya saing yang kuat di tengah kompetisi pendidikan dewasa ini. Penerapan budaya mutu di Madrasah Aliyah Nurul Hikam, Kesambirampak, Kapongan, Situbondo dipercaya dapat mendukung terbangunnya lembaga pendidikan yang unggul yang berdampak pada meningkatnya daya saing lembaga.

Hasil penelitian menunjukkan bahwa, implementasi budaya mutu yang dilakukan Madrasah Aliyah Nurul Hikam dilakukan melalui beberapa tahapan, yaitu : Pertama, merumuskan standar sikap dan perilaku yang berorientasi pada kinerja yang tinggi baik bagi kepala sekolah, staff administrasi, para guru maupun siswa. Perumusan standard ini diwujudkan dalam kode etik yang harus ditegakkan oleh pimpinan, guru, karyawan dan peserta didik sebagi warga madrasah yang menjunjung tinggi pada budaya mutu. Kode etika ini kemudian diintegrasian melalui berbagai macam kegiatan sehari-hari, seperti dalam kegiatan pembelajaran di kelas, yang harus menjunjung tinggi etika, estetika, kedisiplinan, profesionalitas dan berorintasi pada pencapaian target pembelajaran. Hal lain juga dapat dilihat dalam kegiatan rutinitas harian melalui kegiatan pemberian keteladanan pada saat siswa datang ke madrasah. Dalam hal ini, para guru dengan busana rapi menyambut peserta didik dan saling mengucapkan salam, memberikan motivasi serta memberikan teladan tentang kerapian dan kedisiplinan. 
Tahap kedua ialah merumuskan standar pelayanan terbaik yang harus dipatuhi oleh semua warga madrasah untuk meningkatkan mutu layanan kepada pelanggan madrasah, khususnya siswa dan orang tua siswa, melalui pembuatan SOP (Standar Operasional Prosedur). SOP tersebut merupakan petunjuk dan rambu-rambu yang harus dipatuhi oleh warga madrasah dalam menjalankan aktivitas organisasi, baik di dalam kelas maupun di luar kelas, yang meliputi; kecepatan, ketepatan, keramahan, ketanggapan, dan pemberian jaminan mutu di Madrasah Aliyah Nurul Hikam.

Standard pelayanan dalam pembelajaran dalam praktiknya diwujudkan dalam pemberian pelayanan kepada peserta didik secara optimal, mulai dari penyediaan sarana dan pra sarana pembelajaran, penyediaan layanan bimbingan konseling bagi siswa dan layanan pengembangan diri siswa, dan layanan lainnya. Sedangkan pelayanan di luar pembelajaran diwujudkan dalam pemberian informasi kepada wali siswa terkait dengan informasi perkembangan peserta didik agar diketahui oleh wali murid, buku komunikasi antara orang tua dengan wali kelas, dan pemberian informasi lainnya yang mengarah kepada peningkatan layanan kepada pelanggan pendidikan di Madrasah Aliyah Nurul Hikam.

Tahap ketiga ialah pengintegrasian budaya mutu melalui kegiatan yang diprogramkan berupa: kegiatan shalat dzuhur berjamaah, kegiatan pondok ramadhan, kegiatan perayaan pada hari-hari penting, kegiatan kemah bersama, kegiatan ekstra kurikuler, lomba dan kegiatan lainnya. Untuk dapat melaksanakan pengintegrasian budaya mutu melalui kegiatan yang diprogramkan, Madrasah Aliyah Nurul Hikam terlebih dahulu melakukan sebuah perencaan dan pengorganisasian yang matang, agar implemetasinya mudah dan seuai dengan harapan. Guru dan staff juga ditekankan mengikuti kegiatan keagamaan yang telah di programkan oleh pihak madrasah, selain sebagai teladan dan kontrol hal ini juga dimaksudkan agar benar-benar menciptakan suatu iklim atau budaya yang kondusif dan juga menunjukkan komitmen yang tinggi dari pihak madrasah untuk mewujudkan cita-cita dan tujuan madrasah.

Tahap keempat ialah memberikan suatu penghargaan bagi warga madrasah yang memiliki prestasi tinggi dan suatu pembinaan serta bagi yang kinerjanya rendah, baik kepada guru, karyawan maupun kepada peserta didik. Dalam praktiknya terhadap siswa misalnya, pembinaan dilakukan dengan mengevaluasi penerapan metode pembelajaran yang digunakan sehingga akan ditemukan metode pembelajaran yang tepat, dan menganalisis alasan dibalik rendahnya prestasi siswa tersebut. Penerapan metode pembelajaran yang kurang tepat juga bisa mempengaruhi hasil belajar siswa. Sebagaimana diketahui bahwasannya seorang guru yang mampu menggunakan metode pembelajaran yang tepat terhadap siswa, maka idealnya guru tersebut akan mampu menumbuhkan motivasi belajar pada siswa sehingga siswa akan terdorong untuk terus semangat dalam belajar hingga kemudian berhasil 
Al-Tanzim : Jurnal Manajemen Pendidikan Islam E-ISSN: 2549-5720 P-ISSN: 2549-3663

Vol. 03 No. 02 (2019) : 1-12

https:// ejoumal.unija.ac.id/ index.php/al-tanzim

meraih prestasi. Hal ini termasuk pengintegrasian budaya mutu melalui kegiatan pembelajaran, pembentukan budaya mutu di dalam kelas yang menjadi pusat ataupun sumber adalah guru kelas itu sendiri. Jadi dalam hal ini guru memiliki tanggung jawab penuh atas hal tersebut. Pembinaan pada guru ataupun staff ialah dengan mengikutsertakan pada pelatihan-pelatihan dengan harapan bisa menjadikannya lebih professional dan berkualitas.

Tahap kelima ialah memberikan motivasi secara continue kepada seluruh warga madrasah untuk terus meningkatkan mutu kinerjanya agar sesuai dengan standard yang telah ditetapkan guna memenuhi persyaratan yang dituntut oleh lingkungan serta pengguna lulusan (masyarakat). Motivasi tersebut diberikan secara berkala, baik secara langsung maupun tidak langsung, tergantung kepada situasi dan kondisi yang dihadapi. Untuk meningkatkan motivasi warga madrasah, kepala Madrasah Aliyah Nurul Hikam memberikan reward dan punishment kepada setiap individu yang berprestasi ataupun kepada mereka yang melakukan pelanggaran. Melalui hal tersebut, diharapkan mutu menjadi budaya yang harus dipraktikkan dalam aktivitas sehari-hari di madrasah.

Dengan menjadikan mutu sebagai paradigma atau landasan dalam berbagai kegiatan di madrasah, maka diharapkan nantinya siswa MA Nurul Hikam Kesambirampak Kapongan Situbondo selaku pelanggan internal pendidikan akan mendapatkan pelayanan terbaik yang bisa mendorongnya mengembangkan kemampuannya sehingga apa yang menjadi keinginan bisa tercapai sesuai harapan. Sebuah lembaga pendidikan dikatakan bermutu apabila mampu membuat pelanggan puas.

Berbicara mengenai mutu, di bidang pendidikan meliputi 4 mutu yaitu input, proses, output, dan outcome. Pertama, masukan (in put) pendidikan dinyatakan bermutu apabila telah berproses. Kedua, proses pendidikan bermutu jika mampu menciptakan suasana yang aktrif, kreatif dan juga menyenangkan. Ketiga, lulusan (out put) dinyatakan bermutu jika hasil belajar dalam bidang akademik dan nonakademik siswa tinggi. Keempat, out come dinyatakan bermutu apabila lulusan cepat terserap di dunia kerja, gaji yang wajar, dan semua pihak mengakui kehebatannya lulusannya dan merasa puas (Hakim, 2017).

Pendidikan yang bermutu dan unggul merupakan hal yang harus diperhatikan dan diupayakan untuk dicapai. Pendidikan akan menjadi sia-sia apabila mutu proses dan lulusannya rendah. Penilaian dan pengakuan terhadap pendidikan yang mutu dan unggul atau tidak, akan lebih banyak di tentukan oleh masyarakat profesional. Dengan kata lain, bahwa masyarakat profesional yang akan menjadi penilai (quality control) dari lembaga pendidikan yang ada. Kontrol dilakukan dari kemampuan para lulusan lembaga pendidikan tersebut, dengan program-program pembelajarannya, guru di nilai oleh masyarakat (Anggreni, 2016). 
Lembaga pendidikan dapat mencapai tahapan unggul apabila sudah bermutu. Selain bermutu, untuk menjadikan lembaga pendidikan unggul juga diperlukan komitmen dalam diri seluruh stakeholder lembaga, maka untuk dapat menyatukan komitmen tersebut upaya yang dilakukan ialah melatih stakeholder dengan beragam kegiatan yang menunjang mutu menjadi sebuah kebiasaan, atau diistilahkan dengan budaya mutu. Melalui penerapan budaya mutu yang ada di dalamnya, terdapat beragam kegiatan yang dibiasakan pada lembaga pendidikan, secara berangsur lembaga pendidikan tersebut akan sampai pada tahapan unggul. Dikatakan unggul dan bermutu apabila sebuah lembaga pendidikan mampu memberikan kepuasan terhadap pelanggan. Dalam konteks ini lembaga pendidikan unggul ialah lembaga yang menjadi mayoritas pilihan atau kepercayaan oleh orang tua siswa mampu melahirkan lulusan yang terbaik. Hal ini tentunya tercermin dalam visi, misi, capaian akademik maupun non-akademik, serta kegiatan pembelajaran di dalamnya.

\section{KESIMPULAN}

Semakin ketatnya persaingan dalam dunia pendidikan mengharuskan Madrasah Aliyah Nurul Hikam Kesambirampak Kapongan Situbondo selalu berinovasi agar tetap mampu mempertahankan eksistensinya. Membangun budaya mutu pada lembaga pendidikan adalah sebuah keniscayaan. Oleh karena itu, sebagai bagian dari ikhtiar untuk menciptakan madrasah unggul adalah melalui penguatan komitmen dari seluruh civitas madrasah dalam melakukan berbagai aktivitas yang berorientasi atau berparadigma mutu. Dalam budaya tersebut terdapat beragam upaya yang dilakukan dan dijadikan sebuah kebiasaan yang kemudian menjadi sebuah tolak ukur untuk bisa menjadi lembaga pendidikan kepercayaan masyarakat. Ketika setiap warga madrasah telah menyadari pentingnya budaya mutu dalam setiap aktivitas kegiatan, maka visi dalam mencapai madrasah yang unggul dapat dengan mudah direalisasikan. 
Al-Tanzim : Jurnal Manajemen Pendidikan Islam E-ISSN: 2549-5720 P-ISSN: 2549-3663

Vol. 03 No. 02 (2019) : 1-12 https:// ejournal.unija.ac.id/index.php/al-tanzim

\section{DAFTAR PUSTAKA}

Ahmed Hamadtu Ahmed, M., \& Gumaa Siddiek, A. (2012). Strategic Quality Management in the Arab Higher Education Institutes: A Descriptive \& Analytical Study. International Journal of Business and Social Science, 3(24), 90-103.

Amin, N., Siswanto, F., \& Hakim, L. (2018). Membangun Budaya Mutu yang Unggul Dalam Organisasi lembaga Pendidikan Islam. Al-Tanzim; Jurnal Manajemen Pendidikan Islam, 2(1), 80-93.

Anggreni, N. M. (2016). Konstruksi Budaya Mutu Relevansinya Dengan Manajemen Mutu Guru Dalam Pembelajaran Pendidikan Agama Hindu. Jurnal Manajemen Mutu, 2(2), 84-92.

Aole, R. M., \& Gorantiwar, P. V. S. (2013). Quality Gurus: Philosophy and Teachings. International Journal of Research in Aeronautical and Mechanical Engineering, 1(8), 46-52.

Chiar, M. (2009). Budaya Sekolah Unggul. Jurnal Visi Ilmu Pendidikan, 1(2), 163172.

Choiri, M. (2015). Makna School Culture dan Budaya Mutu Bagi Stakeholder di Madrasah Ibtidaiyah Negeri (MIN) Demangan Kota Madiun Tahun Pelajaran 2014-2015. Kodifikasia, 9(1), 147-170.

Hakim, L. (2017). Penataan Pendidikan Islam Bermutu. Jurnal Pendidikan Agama Islam-Ta'lim, 15(1), 17-27.

Hasbullah. (2006). Otonomi Pendidikan. Jakarta: RajaGrafindo Persada.

Jabar, C. S. A. (2011). Pencapaian Keunggulan Pada SMA Negeri Dan Swasta Berkategori Unggul di Kota Bandung. Jurnal Penelitian Pendidikan, 12(2), 86-93.

Kurniawan, S. (2017). Pengembangan Manajemen Mutu Pendidikan Islam Di Madrasah. Al-Tanzim: Jurnal Manajemen Pendidikan Islam, 1(2), 25-36. https://doi.org/10.33650/al-tanzim.v1i2.111

Mandru, L., Patrascu, L., Carstea, C.-G., Popescu, A., \& Birsan, O. (2011). Paradigms of Total Quality Management. Recent Researches in Manufacturing Engineering, 121-126. Retrieved from https://pdfs.semanticscholar.org/c736/e420d36ff59139330ef146987f1db b161db9.pdf

Midun, H. (2017). Membangun budaya mutu dan unggul di sekolah. Jurnal Pendidikan Dan Kebudayaan Missio, 9(1), 50-59. 
Miftachurrohman, A. S., \& Atika. (2018). Manajemen Lembaga Pendidikan Berorientasi Mutu di SMP Ali Maksum Krapyak Yogyakarta. Jurnal Pendidikan Madrasah, 3(2), 473-480.

Mohammady, Z. M. A. (2018). Peran Kepala Sekolah dalam Mengembangkan Mutu Budaya Organisasi. Muslim Heritage, 1(2), 407-430.

Mulyadi. (2010). Kepemimpinan Kepala Sekolah dalam Mengembangkan Budaya Mutu. Malang: UIN Maliki Press.

Pawito. (2007). Penelitian Komunikasi Kualitatif. Yogyakarta: PT. LKIS Pelangi Aksara.

Rahmah, S. (2016). Mengenal sekolah unggulan. Itqan, VII(1), 11-22.

Riyanta, T. (2016). Mengembangkan Budaya Mutu Sekolah Melalui Kepemimpinan Transformasional. Jurnal Manajemen Pendidikan, 12(2), 37-48.

Sagala, S. (2008). Budaya dan Reinventing Organisasi Pendidikan. Bandung: Alfabeta.

Said, A. (2018). Kepemimpinan Kepala Sekolah Dalam Melestarikan Budaya Mutu Sekolah. EVALUASI, 2(1), 257-273.

Saufi, A., \& Hambali. (2019). Menggagas Perencanaan Kurikulum Menuju Sekolah Unggul. Al-Tanzim: Jurnal Manajemen Pendidikan Islam, 3(1), 2954.

Siti Aminah, A. D. W. (2019). Membangun Budaya Mutu di Madrasah Unggul (Studi Kasus di MAN 1 Jember dan MA Unggulan Nurul Islam Jember. Evaluasi, 3(1), 1-29.

Zahroh, A. (2014). Manajemen Sekolah Unggulan: Strategi Pengembangan Kapasitas Sekolah Menuju Pendidikan Bermutu. Ta'allum, 2(2), 147-162. 